\title{
Climate Influenced Challenges of Accessibility to Water by Households Downstream of the Upper Benue River Basin-Nigeria
}

\author{
Vincent Nduka Ojeh ${ }^{\circledR}$, Shadrach Terlumun Semaka \\ Department of Geography, Faculty of Social Sciences, Taraba State University, Jalingo, Nigeria \\ Email: shadrachsemaka@gmail.com,drojehvn@tsuniversity.edu.ng
}

How to cite this paper: Ojeh, V.N. and Semaka, S.T. (2021) Climate Influenced Challenges of Accessibility to Water by Households Downstream of the Upper Benue River Basin-Nigeria. Atmospheric and Climate Sciences, 11, 53-72.

https://doi.org/10.4236/acs.2021.111004

Received: October 22, 2020

Accepted: January 1, 2021

Published: January 4, 2021

Copyright (c) 2021 by author(s) and Scientific Research Publishing Inc. This work is licensed under the Creative Commons Attribution International License (CC BY 4.0).

http://creativecommons.org/licenses/by/4.0/

\begin{abstract}
The study examined climate influenced challenges of accessibility to water by households downstream of the Upper Benue River Basin, Nigeria. Literatures related to the topic being investigated were reviewed. The study adopted a descriptive survey design. The population of the study consisted of communities in Adamawa, Gombe, Bauchi and Taraba states. Eight different communities, two in each local government were sampled for the study. Simple random and purposive samplings were used for the study. A total of 351 respondents were selected for the study using Krejcie and Morgan sample size determination. Data analysis was done using frequency tables percentages and mean statistics. The findings of the study showed that climate variability has great impact on water stress and threats to households' downstream in Upper Benue River basin represented with a mean 3.85 (decrease in the quality and quantity of surface water) as well as 3.43 (drying up of rivers and lakes). The study also revealed that water stress induced by climate variability has a significant effect on household livelihoods represented by $87 \%$ of the respondents in the study area. It was also revealed that that households downstream the basin are vulnerable to climate change and households in the study area have development strategies to contend with water stress so as to better their livelihood among which is surface water harvesting (2.78), reducing the number of times dishes are washed (2.96), reducing the quantity of water used for bathing (3.0) among others. The study recommended that stakeholders and the government should make proactive efforts to ensuring that alternative water sources are established in the study area to reduce water stress among the rural populace.
\end{abstract}

\section{Keywords}

Upper Benue River Basin, Accessibility, Households, Water Challenges 


\section{Introduction}

Variability in climate has negatively affected human and human dependent livelihood systems in Africa. Water is one indispensable resource in the northeast region of Nigeria for the sustainability of all aspect of lives; from farming to domestic use yet it has become the most difficult to access by families. Water in its natural form is limited in supply as proportion of it is stored in the atmosphere as cloud while others are stored underground in aquifers, oceans, rivers and streams. This is the genesis of the water challenge debacle. Water in the environment, in global, regional and national economies, and the societies and polities in which these are embedded, is universally regarded as an essential commodity and frequently an appreciated amenity [1]. This gives credence to the fundamental role of water in the sustenance of life and livelihood of humans and societies. Water is a universal resource which, because of its free occurrence in nature, is often taken for granted and abused, especially in third world nations where information is neither readily accessible, nor disseminated to society. Abundant as it may seem, water, in its clean state, is one of the rarest elements in the world [2].

Water is derived from various sources such as the ocean water constituting $97 \%$ of the earth's water, ice $2 \%$, and $1 \%$ fresh water obtained from the rivers, lakes, underground water, the atmospheric and soil moisture [3]. Water, as it is generally alluded to, sustains life. It is impossible to survive without the availability of water. Water has been viewed as the global common heritage and everyone should, albeit effectively, have an inalienable social and political right to it. However, fresh water shortage has been noticed around the globe [4] [5]. The challenges of water supply have constituted a factor inducing conflicts in some parts of the world because the earth's fresh water is diminishing due to man's activities and climate change. Nigeria as a nation is in no way disassociated from the challenges of water supply.

Access to water is measured by the number of people who have reasonable means of getting an adequate amount of water that is safe for drinking, washing and essential household activities expressed as a percentage of the total population. It reflects the health of a country's people and the country's capacity to collect, clean and distribute water to consumers. Safe water includes treated surface water, as well as untreated but uncontaminated water from source such as natural springs and sanitary wells and protected boreholes. On average, a person needs about 20 liters of safe water each day to meet his or her daily metabolic, hygiene and domestic needs. In urban areas the source may be public standpipe located not more than 200 meters away. In rural areas the definition implies that members of the household do not have to spend a disproportionate part of the day fetching water [6]. On the other hand, the lack of access to adequate safe water supply contributes to death and illness, especially in children. Thus, the improvement of access to water is a crucial element in the reduction of underage mortality, morbidity, particularly in poor rural areas. Access to water also means that considerable amount of time women and children spend in fetching water 
could be used more effectively on other tasks, a key component in poverty alleviation efforts. Most but not all, of these people live in low-income countries and those at greatest risk are children and the elderly. According to [7], millions of people worldwide suffer from other water related diseases such as bilharzias, cholera and hookworm. Improvement in water supply and sanitation services tend to lead to improvement in people's health and quality of their lives.

Water accessibility and use fall into several major classes, each of which is associated with certain quantity and quality requirements [7]. These classes include water for drinking and cooking, waste disposal, crop production, aquaculture, livestock, industrial use, recreational use, navigational uses, and ecological values such as survival of natural lake, riverine or wetland communities. The quantity of water required for activities within each of these classes is influenced mainly by variables such as climate and precipitation. The proportion of total water used for any specific purpose is controlled by socioeconomic conditions, tradition, culture and water availability. Water availability will become more unreliable with increased climate variability, aggravating the situation in water-stressed regions and generating similar problems in areas that have not yet been as severely affected. Water related disasters will become more frequent and severe. "Food security, human health, urban and rural settlements, energy production, industrial development, economic growth, and thriving ecosystems are all water-dependent and thus vulnerable to the impacts of climate change" [8].

Poor access to improved water in Nigeria and other West African countries remains a major contributing factor to high morbidity and mortality rates among children under five [9]. "The use of contaminated drinking water and poor sanitary conditions result in increased vulnerability to water-borne diseases, including diarrhoea which leads to deaths of more than 70,000 children under five annually" [10]. The capacity of particular household to adjust to changes in climatic parameters depends in large part on the specific political, economic, institutional and biophysical factors that structure household activities [11]. Our understanding of the capacity of households to adapt to climatic change has been constrained by the limitations of climate models in accounting for the full complexity of changing social circumstances in climatic variability and water stress [11]. While it falls under the purview of government at all levels through the Ministry of Water Resources to provide water, the reverse is the case as Nigerians provide their own water through the construction of boreholes. This alternative source of water appears to constitute a looming danger for $\mathrm{Ni}$ gerians as most of these boreholes are exposed to underground pathogens and pollutants especially $E$-coli which cause diarrhoeal diseases, which are also contributing factors to malnutrition and child mortality [11].

Warmer temperatures will accelerate the hydrological cycle, altering precipitation, the magnitude and timing of runoff, and the intensity and frequency of floods and droughts. It has been noted 37 percent of Nigerian households had challenges accessing clean water and this was mostly prevalent in the northern region; North-West and North-Central to be specific (see Appendix Figure 
A1(a) \& Appendix Figure A1(b)). From the foregoing, it is pertinent to note that people and communities around these local government areas (Karim Lamido, Lau, Numan, Demsa, Yamultu and Tafawa Belewa) due to the variability and fluctuation in climatic conditions are faced with different challenges of water accessibility resulting from flood and drought. They are often forced to leave their communities for safety and water challenge has become a perennial problem they have to contend with. It is in the light of the above that the study seeks to assess the climate influenced challenges of accessing water by households downstream of the upper Benue River Basin.

\section{Objectives of the Study}

This study assessed the climate influenced challenges of accessibility to water by households downstream of the Upper Benue River Basin, Nigeria. The specific objectives of the study are:

1) Assess the demographic characteristics of the respondents in the study area;

2) Investigate the magnitude of climate-influenced water stress and its impacts on household livelihoods and the responses by households in the study area.

\section{Empirical Review}

According to WHO [12] about 663 million people worldwide had no access to adequate drinking water supplies, and nearly half of the people using unimproved water sources live in sub-Saharan Africa [13]. Although, Nigeria is blessed with abundant water resources (estimated at 226 billion cubic meters of surface water and about 40 billion cubic meters of ground water) her rural populations are largely deprived and lack access to adequate water supplies [14]. About 65 million Nigerians have no access to safe and adequate water supplies; the number rose dramatically to 90 million in 2015 [13].

In a study of water supply in Wukari town through partnership approach, Ishaku et al. [7] noted that the water demand for the northeast Nigeria was 30 1/p/d. World Bank estimates that an average 20 - 50 liters of safe water is needed by an individual for daily metabolic and hygiene. This figure is slightly above the national water requirements for Nigeria which pegs it at $23 \mathrm{l} / \mathrm{p} / \mathrm{d}$ for rural areas and $60 \mathrm{l} / \mathrm{p} / \mathrm{d}$ for urban areas. In the same vein, [15] estimates that $12 \%$ of the world's population consumes $80 \%$ of the available water, leaving 1.1 billion people (1/6th of world population) without access to adequate water supplies. This is aggravated by the fact that 2.4 billion people lack access to adequate sanitation facilities. It is estimated that by 2025 water shortages could affect two out of three persons globally, with developing nations most vulnerable. As young people make up higher population of developing countries relative to developed countries, they are disproportionately at risk.

According to the World Health Organization [12], while seventy-five percent (75\%) of the urban population is served by improved water supply, people in the suburbs get their water from water vendors hauling it from a distant river, 
stream or public boreholes after collecting it in containers on four wheeled carts. In rural areas, only about $42 \%$ of households have access to safe water [12]. The human resources required to manage the water resources of the country are available within the country; however, the resources are not equitably distributed, as workers prefer working in urban rather than rural areas [12].

Nigeria receives water volume of $25 \mathrm{~km}^{3} / \mathrm{yr}$ from Cameroon via the Benue River. A significant proportion of the Nigerian rural population continue to use rivers, ponds, lakes and harvested rain as their main sources of water supply [16]. This category of Nigerians faces great risks to their health and wellbeing [17]. The rural areas generally exhibit great poverty, decayed infrastructure, poor health conditions, low access to social facilities and ignorance as a result of varying degrees geographical and political isolation [18].

Ishaku et al., [7] observed that many rural communities in Nigeria do not have improved water supply systems such as piped water networks or boreholes. In locations where such facilities exist; they are either malfunctioning or completely breaking down and this force households within the neighbourhoods to rely on available sources for domestic purposes. Women and children especially spend their productive and considerable time seeking for water in far distances from their homes. They rely solely on self-water supply source. Households not having access to improve water supply are vulnerable to many health problems. These water supply sources include shallow wells, rivers, springs, ephemeral streams and rainwater.

The limited access to water supplies by a significant proportion of the Nigerian rural population has been blamed on institutional and socio-economic factors [19]. Toyobo and Tanimowo [20] attributed the prevailing water poverty in many rural communities of Nigeria, to poor sustainability of water infrastructure, paucity of funds, inadequate technology and lack of political will. Olaleye [21] and Akpomuvie [22], have noted that the provision of adequate, clean, reliable, and potable water in Nigerian rural areas remains a challenge which needs to be tackled considering the fact that a larger percentage of the population live in rural areas. When the water is inadequate, people are compelled to use contaminated water which may later create health problems, including the outbreak of diseases [23].

Climate change undermines crop production; resulting to large risks on food insecurity globally [24]. Africa is one of the most vulnerable regions to climate change in the world. Previous assessments [25] [26] concluded that Africa is particularly vulnerable to the impacts of climate change because of factors such as widespread poverty, recurrent droughts, inequitable land distribution and over dependence on rain-fed agriculture [27]. Climate change and climate variability impose limitations to crop growth, it also affects the choice of crop species and cultivars and other farm management decisions [28].

\section{Methodology}

\section{Study Area}


Description/Location: The upper Benue River Basin is one of the eleven (11) River basin Development Authorities established under Decree No. 25 of 1976 (as amended by decree No.87 of 1979). The headquarters of the authority is located along Mbamba-Fufore Road in Yola, Adamawa state. With the amended decree of 1979, the functions of the Authority like other River Basins in the country are limited to development of water resources potentials within its defined areas of jurisdiction. The Upper Benue River Basin which is the study area is located at Latitude $093030^{\prime}$ and $11000^{\prime} \mathrm{N}$ and longitude $11030^{\prime} \mathrm{E}$.

The area of operation of the Upper Benue River basin covers the whole of Taraba and Gombe states. Also, two senatorial districts in Adamawa state, and one senatorial district in Bauchi state. Agriculture is the main occupation of the inhabitants who engages mostly in the production of cereal crops, vegetables, and animal husbandry. The nature of the agricultural practices has made the people within the catchment states of the authority to live in rural areas where basic amenities such as portable water, electricity, good roads, and health facilities, among others are lacking.

Climate: The area around the upper Benue basin has a tropical continental climate well marked by wet and dry season. The wet season usually commence around late April, ends in October while the dry season commence in November, and ends in March. The dry season is characterized by the prevalence of the Northeast trade winds from the Sahara desert.

Socio-economic activities: The people of the upper Benue river basin belong to different diverse ethnic groups and communities. The make-up of the population of the area cannot be divorced from historical, geographical, administrative and political experiences of the area of the years. The diversity of the people in terms of ethnic, religious, social and economic affiliations and status is consistence with the position of the area. The indigenous people of this are mainly the Jenjo, Bandawa, Wurkun, Bachama, Mbula, Dadiya, Tangale, and Shomo. There exist also a significant member of other tribes like Igbo and Yoruba from the southern part of the country. In terms of their economic activities, the people of Jalingo local government area are mainly farmers, fishers and traders. Crops grown in this area include maize, groundnut, Yam, Millet, Beans, Rice, Fruits and Vegetables.

There are farms, gardens, mango trees, baobabs, shrubs and a number of grasses. However, increase in human population with its concomitant demands for housing; fuel wood and poor land management have great impact on the natural vegetation thereby reducing it drastically.

Research design: The research design that was used for this study is the descriptive survey. In descriptive survey, the researcher selects a sample of respondents from a population and administers a standardized questionnaire to them. Using stakeholders' participation approach, survey will be carried out with the aid of physical site visits, interviews through questionnaire administration. Site visit and transect was undertaken to assess the available water sources, land use, socio-economic status, access to infrastructure within the area. Personal obser- 
vations and photographs were taken where necessary, to substantiate the observations made.

Population of the study: The population of the study involves the selected communities of Adamawa, Gombe, Bauchi and Taraba state; this will cut across four local Government; Numan, Demsa, Tafawa Belawa, Yamultu, Lau and Karim Lamido on the basis of the location on the course of Benue River. The study sites vary in terms of environmental conditions, level of rurality as well as access to infrastructure, goods and services. Eight different communities, two in each local government area were selected under the category of water scarcity and stressed communities, villages with high population density, economic and agricultural activities.

Sample and sampling techniques: Simple random sampling and purposive sampling was used. The sample size was determined using Krejcie and Morgan Table for sample size determination. In view of the above, a total of 351 copies of questionnaires were distributed to eight selected communities.

Data collection techniques: Data for this study was collected from both primary and secondary sources. Secondary sources involve the use of textbooks, journals and online articles that was collected for this study. Data for the study was collected using interview schedule. The primary source involves the use of questionnaire. We divided the questionnaire used for the study into sections based on the objectives of the study. These sections seek information on the demographic and the socio-economic characteristics of respondents, the major sources of water for households in the area the seasonality of water resources, changes in the volume of water bodies over the years, the perceived effects of climate change on water resources, the average quantity of water used by households per day, household's water demand management strategies influenced by climate change, the approaches to community water management in the area and the strategies adopted for ameliorating the effects of climate change on water resources.

Data analysis: Data collected from the field was subjected to statistical analysis using descriptive statistics. Frequency counts and percentage will be used for analyzing the demographic characteristics of the respondents. Frequency counts and mean will be used to analyze the research questions. The four-point Likert scale will be assigned numerical values thus: SA (Strongly Agree) $=4$; A (Agree) $=3 ; \mathrm{D}($ Disagree $)=2$, and SD (Strongly Disagree) $=1$. This implies that 2.5 is the decision mean. Thus, any mean score from 2.5 will be accepted as been significant but any mean score below 2.5 will be rejected.

\section{Results/Discussion}

Data from Table 1 shows that $42.7 \%$ of the respondents are male respondents while $57.3 \%$ of the respondents are female respondents making a total of 351 responses. The responses show that $27.9 \%$ are between the ages of $18-27$ years, $29.1 \%$ are between the ages of $28-37,22.2$ are in $38-47$ age bracket, while 
Table 1. Demographic characteristics of respondents.

\begin{tabular}{|c|c|c|}
\hline ITEM & FREQUENCY & PERCENTAGE (\%) \\
\hline \multicolumn{3}{|l|}{ Gender } \\
\hline Male & 150 & 42.7 \\
\hline Women & 201 & 57.3 \\
\hline \multicolumn{3}{|l|}{ Age } \\
\hline $18-27$ & 98 & 27.9 \\
\hline $28-37$ & 102 & 29.1 \\
\hline $38-47$ & 78 & 22.2 \\
\hline $48-57$ & 73 & 20.7 \\
\hline 58 and above & - & - \\
\hline \multicolumn{3}{|l|}{ Marital Status } \\
\hline Married & 193 & 54.9 \\
\hline Single & 73 & 20.9 \\
\hline Divorced & 77 & 21.9 \\
\hline Widow & 8 & 2.2 \\
\hline \multicolumn{3}{|l|}{ Educational Level } \\
\hline No formal education & 78 & 22.2 \\
\hline Primary school attempted & 31 & 8.8 \\
\hline Primary school completed & 73 & 20.7 \\
\hline Secondary school attempted & 35 & 9.9 \\
\hline Secondary school completed & 82 & 23.3 \\
\hline $\mathrm{OND} / \mathrm{NCE}$ & 36 & 10.2 \\
\hline HND/First Degree & 16 & 4.5 \\
\hline Higher Degrees (MSc, PhD) & - & - \\
\hline \multicolumn{3}{|l|}{ Religion } \\
\hline Christianity & 307 & 87.4 \\
\hline Islam & 44 & 12.5 \\
\hline \multicolumn{3}{|l|}{ Household Size } \\
\hline $1-5$ & 98 & 27.9 \\
\hline $6-10$ & 102 & 29 \\
\hline $11-15$ & 78 & 22.2 \\
\hline $16-20$ & 73 & 20.7 \\
\hline 20 and above & - & - \\
\hline \multicolumn{3}{|l|}{ Occupation } \\
\hline Farming & 28.1 & 80 \\
\hline Trading & 44 & 12.5 \\
\hline Civil/Public Service & 17 & 4.8 \\
\hline Artisans & 9 & 2.5 \\
\hline
\end{tabular}

Source: Field survey, 2019. 
$20.7 \%$ are within the age range of 48 - 57. The responses showed that $54.9 \%$ of the respondents are married, $20.9 \%$ are single, and $21.9 \%$ of the respondents are divorced while $2.2 \%$ of the respondents are widowed. $22.2 \%$ of the respondent has no formal education, $8.8 \%$ of the respondents are Primary school attempted respondents, $20.7 \%$ are Primary school completed, and $9.9 \%$ of the responses are Secondary school attempted. Similarly, $23.3 \%$ of the respondents are Secondary school completed, $10.2 \%$ of the responses are OND/NCE holders while $4.5 \%$ of the respondents are HND/First Degree holders. $87.4 \%$ of the respondents are Christians while $12.5 \%$ Islam. Table 1 shows the distribution of Questionnaire based on Household Size. The responses show that $27.9 \%$ of the respondents are within a household of 1 - 5 people, 29\% are within household of 6 - 10 people while $22.2 \%$ are living in a household of 11 - 15 people respectively. $80 \%$ of the respondents are farmers, $12.5 \%$ of the respondents are into trading, $4.8 \%$ are civil/public servants and $2.5 \%$ of the respondents are artisans. This can be inferred that most of the respondents are predominantly farmers.

Data in Table 2 shows that water obtained from well within the household is used for domestic consumption within an average distance of 10 - 30 minutes to the source water. The result also shows that the public well also supplies water for domestic uses within 20 - 50 minutes of stress walking to the source. Similarly, it also shows that tap within neighbourhoods also supplies water for domestic use within 5 - 15 minutes to the source just at public tap also supplies water for domestic use within the time span of 15 - 25 minutes. Other sources of water for domestic use are Borehole which provides water for domestic use within the time span of 20 - 40 minutes distance to source. River/Streams/Springs are used for irrigation, livestock, fishing within the duration of 1 - 20 hours. Table 2 also shows rain water is also used for domestic use within the time frame of $1-5$

Table 2. Showing source of water, source used and distance from house.

\begin{tabular}{|c|c|c|c|}
\hline $\mathrm{S} / \mathrm{N}$ & Source & $\begin{array}{c}\text { Source used (Farming, livestock, } \\
\text { fishing, irrigation and domestic uses) }\end{array}$ & $\begin{array}{c}\text { Distance from your } \\
\text { House (in time) }\end{array}$ \\
\hline 1 & Well within home & Domestic uses & 10 - 30 minutes \\
\hline 2 & Public well & Domestic uses & $20-50$ minutes \\
\hline 3 & $\begin{array}{l}\text { Tap within } \\
\text { neighbourhood }\end{array}$ & Domestic uses & 5 - 15 minutes \\
\hline 4 & Public tap & Domestic uses & 15 - 25 minutes \\
\hline 5 & Bore hole & Domestic uses & $20-40$ minutes \\
\hline 6 & River/streams/springs & Farming/livestock, fishing irrigation & $1-2$ hours \\
\hline 7 & Rain water & Domestic uses & 1 - 5 minutes \\
\hline 8 & Tanker/water vendors & Domestic uses & $30-1: 30$ minutes \\
\hline 9 & Sachet/caned water & Domestic uses & 5 - 30 minutes \\
\hline 10 & Ponds & Farming/livestock, fishing irrigation & $1-2$ hours \\
\hline
\end{tabular}

Source: Field survey, 2019. 
minutes. The respondents also said that sachet/canned water is use for domestic purposes and can be obtained within 5 - 30 minutes. Tankers also supply water to the respondents within 30 minutes to 1 hour 30 minutes for domestic use while ponds supply water for irrigation and livestock farming.

Table 3 shows that in the core dry season months of the year i.e., November, December, January and February that the main source of water for residents of the study area are River Benue augmented with the purchase of sachet water while in the transition to rainy season months of March, April and May, the residents rely on the River Benue, water vendors augmented with the purchase of sachet water. This is because, apart from river Benue, all rivers and streams dry up during the dry season and transition to rainy season months in the area as result of climate conditions of very high evaporation. However, during the rainy season months of June, July, August, September and October, the residents depend on River Benue, rainwater and sachet water with less need for water vendors. The sachet water is in demand in all months of the year since it is perceived to be potable for drinking as treated water and in high demand during the dry season months.

Table 4 shows the perceived effects of climate variability, trend, perception and awareness of the respondents. The result shows that respondents with a mean of 1.34 disagreed that climate variability lead to increase in the quality of surface water. The respondents however agreed with a mean 3.85 that climate variability leads to decrease in the quality of surface water. The respondents disagreed with a mean of 1.31 that climate variability leads to improvement in the quality of groundwater as can be seen in item 3 of the above table. In item (5) the respondents also agreed with a mean of 3.19 that climate variability results to Increase in groundwater level. The respondents agreed with a mean of 3.12 that

Table 3. Sources of water for household in different months of the year.

\begin{tabular}{|c|c|c|c|}
\hline \multirow{2}{*}{$\begin{array}{l}\text { Months } \\
\text { January }\end{array}$} & \multicolumn{3}{|c|}{ Water sources } \\
\hline & River Benue & - & Sachet water \\
\hline February & River Benue & - & Sachet water \\
\hline March & River Benue & water vendor \& & Sachet water \\
\hline April & River Benue & water vendor \& & Sachet water \\
\hline May & River Benue & water vendor \& & Sachet water \\
\hline June & River Benue, rain water & water vendor \& & Sachet water \\
\hline July & River Benue, rain water & - & Sachet water \\
\hline August & River Benue, rain water & - & Sachet water \\
\hline September & River Benue, rain water & - & Sachet water \\
\hline October & River Benue, rain water & - & Sachet water \\
\hline November & River Benue & - & Sachet water \\
\hline December & River Benue & - & Sachet water \\
\hline
\end{tabular}

Source: Field survey, 2019. 
Table 4. Awareness and perceived effects of climate variability trends on water.

\begin{tabular}{|c|c|c|c|c|c|c|c|}
\hline$S / N$ & Phenomena & SA & A & $\mathrm{D}$ & SD & Mean & Decision \\
\hline 1 & Increase in the quality of surface water & & & 120 & 231 & 1.34 & Disagree \\
\hline 2 & Decrease in the quality of surface water & 301 & 50 & & & 3.85 & Agree \\
\hline 3 & Improvement in the quality of groundwater & & & 109 & 242 & 1.31 & Disagree \\
\hline 4 & Improvement in the quality of groundwater & 20 & 231 & & & 2.2 & Disagree \\
\hline 5 & Increase in groundwater level & 69 & 282 & & & 3.19 & Agree \\
\hline 6 & Decrease in groundwater level & 43 & 308 & & & 3.12 & Agree \\
\hline 7 & Shrinking of surface water & 127 & 224 & & & 3.36 & Agree \\
\hline 8 & Drying up of rivers and lakes & 151 & 202 & & & 3.43 & Agree \\
\hline 9 & Increase in water-borne diseases & 191 & 160 & & & 3.5 & Agree \\
\hline 10 & Increase in the amount of money spent on water & 281 & 70 & & & 3.8 & Agree \\
\hline 11 & Increased frequency of flooding & 349 & 2 & & & 3.9 & Agree \\
\hline 12 & Increase in frequency of drought & 351 & & & & 4.0 & Agree \\
\hline 13 & Decrease in frequency of drought & 300 & 51 & & & 3.8 & Agree \\
\hline 14 & High intensity rainfall & 201 & 150 & & & 3.5 & Agree \\
\hline 15 & Low intensity rainfall & 251 & 100 & & & 3.7 & Agree \\
\hline 16 & More intense and frequent storms & 48 & 300 & 3 & & 3.1 & Agree \\
\hline 17 & Less intense and frequent storms & 101 & 299 & 41 & & 3.9 & Agree \\
\hline 18 & More intense and frequent heat waves & 72 & 279 & & & 3.2 & Agree \\
\hline 19 & $\begin{array}{l}\text { Increased energy and time spent on } \\
\text { water collection }\end{array}$ & 152 & 199 & & & 3.4 & agree \\
\hline 20 & Higher water temperatures & 30 & 321 & & & 3.0 & Agree \\
\hline 21 & Lower water temperatures & 322 & 29 & & & 3.9 & Agree \\
\hline 22 & Salinization of groundwater & 246 & 99 & 6 & & 3.6 & Agree \\
\hline 23 & Increased spread of water-related diseases & 181 & 170 & & & 3.5 & Agree \\
\hline 24 & Increased incidence of wildfire & 159 & 192 & & & 3.4 & Agree \\
\hline 25 & Increased erosion & 349 & 2 & & & 3.9 & Agree \\
\hline 26 & $\begin{array}{l}\text { Increased mortality among young fish due to } \\
\text { rising water temperatures in lagoons and lakes }\end{array}$ & 29 & 322 & & & 3.0 & Agree \\
\hline 27 & Loss of some fish species & 177 & 174 & & & 3.5 & Agree \\
\hline 28 & $\begin{array}{l}\text { Disruption of safe water supplies through } \\
\text { flood damage to infrastructure }\end{array}$ & 340 & 11 & & & 3.9 & Agree \\
\hline 29 & Loss of crops to floods & 351 & & & & 4.0 & Agree \\
\hline 30 & Loss of lives and property to floods & 341 & 10 & & & 3.9 & Agree \\
\hline 31 & Increased conflict over water resources & 2 & 349 & & & 3.0 & Agree \\
\hline 32 & $\begin{array}{l}\text { Increase wilting of crops } \\
\text { in the field due to moisture }\end{array}$ & & 348 & 3 & & 2.9 & Agree \\
\hline 33 & Early onset of rainfall & 351 & & & & 4.0 & Agree \\
\hline 34 & Late onset of rainfall & 351 & & & & 4.0 & Agree \\
\hline 35 & Early cessation of rainfall & & 351 & & & 3.0 & Agree \\
\hline 36 & Late cessation of rainfall & 351 & & & & 4.0 & Agree \\
\hline 37 & Others specify & & & & & & \\
\hline
\end{tabular}

Source: Field survey, 2019. 
climate variability results to decrease in groundwater level. In item (7), the respondents agreed with a mean of 3.36 that climate variability leads to shrinking of surface water. Item (8) shows a mean of 3.43 level of agreement when the respondents were asked whether climate variability leads to drying up of rivers and lakes.

Table 5 shows the respondent's source of information on climate variability. 93.7\% said they are aware of climate variability through media while $6.2 \%$ said it was through neighbours.

Table 6 shows the intra-household role in household water provision. Data obtained from the respondents show that women and girls are responsible for the provision of household drinking water in the study area, as well as provision of household water for cooking, laundry, bathing, and home cleaning. Provision of water for livestock and fish farms is predominantly done by boys and women while men primarily do the provision of water for irrigation as water for household crafts is provided by boys and girls respectively.

The data presented in Table 7 shows the quantity of water uses per day by different households. In the first option, a given household used 5 quantities of 20 litres yellow jerry can (100 litres) when there is no water stress and used 2 of the same jerry can during water stress (40 litres). Similarly, a household that uses 7 quantities of 25 litres yellow jerry can when there is no water stress (175 litres) and 3 quantity of the same 25 litres jerry can during water stress (75 litres). Again,

Table 5. Respondent's source of information on climate variability.

\begin{tabular}{ccc}
\hline Option & Frequency & Percentage (\%) \\
\hline Media & 329 & 93.7 \\
Neighbours & 22 & 6.2 \\
Total & 351 & 100 \\
\hline
\end{tabular}

Source: Field survey, 2019.

Table 6. Intra-household gender role in household in water provision.

\begin{tabular}{ccccccc}
\hline S/N & Activities & Men & Women & Boys & Girls & $\begin{array}{c}\text { Any } \\
\text { Gender }\end{array}$ \\
\hline 1 & Provision of household drinking water & 6 & 106 & 67 & 172 & - \\
2 & Provision of household water for cooking & - & 103 & 70 & 178 & - \\
3 & Provision of household water for laundry & 17 & 95 & 60 & 179 & - \\
4 & Provision of household water for bathing & 7 & 80 & 75 & 171 & 18 \\
5 & Provision of water for home cleaning & 15 & 97 & 51 & 177 & 21 \\
6 & $\quad$ Watering of livestock & 6 & 106 & 170 & 69 & - \\
7 & Irrigation of farms & 169 & 70 & 107 & 5 & - \\
8 & Provision of water for household fish farms & 5 & 107 & 171 & 68 & - \\
9 & Provision of water for household crafts & 60 & 7 & 171 & 113 & - \\
\hline
\end{tabular}

Source: Field survey, 2019. 
Table 7. Quantity of water used per day.

\begin{tabular}{lcc}
\hline Quantity of water & Number used without water stress & Number used during water stress \\
\hline 20 yellow jerry can & 5 & 2 \\
25 yellow jerry can & 7 & 3 \\
30 yellow jerry can & 4 & 2 \\
35 yellow jerry can & 8 & 2 \\
40 yellow jerry can & 4 & 1 \\
45 yellow jerry can & 8 & 2 \\
50 yellow jerry can & 5 & 3 \\
\hline
\end{tabular}

Source: Field survey, 2019.

a household that uses 4 of 30 litre yellow jerry can when there is no stress (120 litres) reduces it to 2 jerry can during water stress (60 litres). Furthermore, a household that uses 8 of 35 litres yellow jerry can (280 litres) reduces to 2 during water stress period (70 litres) as a household that uses 4 of 40 litres yellow jerry can (160 litres) reduces it to 1 (40 litres), while a household that uses 8 quantity of 45 litre (360 litres) reduces it to 2 during water stress period (90 litres) and a household that uses 50 litres of 5 yellow jerry can (250 litres) reduces it to 3 during water stress period (150 litres) respectively. This shows that during water stress, the households minimize the level of water consumption in the study area.

The data presented in Table 8 is on the household water demand management strategies influenced by climate variability. In item one of Table 8 , the respondents disagreed with a mean of 1.47 on whether they patronize water vendors as water management strategy. The respondents however agreed with a mean of 2.78 above the decision rule that surface water harvesting is the strategy they adopt as a management strategy for water stress as can be seen in item 2 of Table 8. In item 3, the respondents disagreed with a mean of 1.0 that improving underground water is a strategy used by them in managing water stress. Similarly, a mean of 2.0 below the decision rule was obtained when the researcher sought to know whether the respondents use alum for purifying water as can be seen in item 4 of the table above. In item 5 , the respondents still disagreed that checking for and reduction of leaks on taps is water management strategy adopted by them to reduce water stress with a mean of 1.26 . The respondents also disagreed that boiling of drinking water reduces water stress with a mean of 1.20 below the mean criterion. The respondents also disagreed with a mean of 1.02 on whether Rainfall enhancement (e.g. engaging the services of rain makers) is the strategy adopted by them to reduce water stress in the study area as can be seen in item 7 of Table 8. In item 8, the respondents disagreed with a mean of 1.10 was obtained when the researcher sought to know whether the use of low-flush toilets is a strategy for water management. Similarly, responses obtained in item 9 shows a mean of 1 below the accepted criterion on whether Gray water re-use (use of wastewater or reclaimed water from one application such as 
Table 8. Determination of household water demand management strategies occasioned by climate variability.

\begin{tabular}{|c|c|c|c|c|c|c|}
\hline$S / N$ & $\begin{array}{l}\text { Household water } \\
\text { management strategies }\end{array}$ & $\begin{array}{l}\text { Not at } \\
\text { all (1) }\end{array}$ & $\begin{array}{l}\text { Sometimes } \\
\text { (2) }\end{array}$ & $\begin{array}{l}\text { Always } \\
\text { (3) }\end{array}$ & Mean & Decision \\
\hline 1 & Patronizing water vendors & 217 & 101 & 33 & 1.47 & Disagreed \\
\hline 2 & Surface water harvesting & 3 & 69 & 279 & 2.78 & Agreed \\
\hline 3 & Improving underground water & 351 & - & - & 1.0 & Disagreed \\
\hline 4 & Use of alum for purifying water & 28 & 264 & 59 & 2.0 & Disagreed \\
\hline 5 & Checking for and reduction of leaks on taps & 287 & 35 & 29 & 1.26 & Disagreed \\
\hline 6 & Boiling of drinking water & 297 & 36 & 18 & 1.20 & Disagreed \\
\hline 7 & $\begin{array}{l}\text { Rainfall enhancement } \\
\text { (e.g. engaging the services of rain makers) }\end{array}$ & 317 & 30 & 4 & 1.02 & Disagreed \\
\hline 8 & Use of low-flush toilets & 328 & 10 & 13 & 1.10 & Disagreed \\
\hline 9 & $\begin{array}{l}\text { Gray water re-use (use of wastewater } \\
\text { or reclaimed water from one application } \\
\text { such as municipal wastewater treatment } \\
\text { for another application such as } \\
\text { landscape watering) }\end{array}$ & 351 & - & - & 1 & Disagreed \\
\hline 10 & $\begin{array}{l}\text { Reducing the number of times } \\
\text { dishes are washed per day }\end{array}$ & 3 & 6 & 342 & 2.96 & Agreed \\
\hline 11 & $\begin{array}{l}\text { Reducing the number of } \\
\text { baths per household member }\end{array}$ & 9 & 5 & 337 & 2.93 & Agreed \\
\hline 12 & $\begin{array}{l}\text { Engaging in collective laundry } \\
\text { for the household }\end{array}$ & 12 & 20 & 319 & 2.87 & Agreed \\
\hline 13 & $\begin{array}{l}\text { Reducing the quantity of } \\
\text { water used in bathing }\end{array}$ & - & - & 351 & 3.0 & Agreed \\
\hline 14 & $\begin{array}{l}\text { Use of drought tolerant } \\
\text { crops in home gardens }\end{array}$ & 9 & 28 & 314 & 2.86 & Agreed \\
\hline 15 & $\begin{array}{l}\text { Watering of gardens in the morning \& } \\
\text { evening only to reduce evaporation }\end{array}$ & 139 & 71 & 68 & 1.38 & Disagreed \\
\hline
\end{tabular}

Source: Field survey, 2019.

municipal wastewater treatment for another application such as landscape watering). This indicates that the people of the study area do not adopt this strategy. On the contrary, a mean of 2.96 above the mean magnitude was obtained on whether the respondents reduce the number of times dishes are washed per day as a management strategy to reduce water stress. The respondents also agreed with a mean of 2.93 on whether reducing the number of baths per household member can reduce water stress in the study area. In item 12 , a mean of 2.87 was obtained. This shows that the respondents agreed that engaging in collective laundry for the household can reduce water stress in the study area. Similarly, reducing the quantity of water used in bathing is another water management strategy adopted in the study area as 3.0 mean above the criterion was obtained in affirmative as can be seen in item 13 of Table 8 . The respondents also agreed with a mean of 2.86 that use of drought tolerant crops in home gardens is a 
strategy for water management as obtained in item 14. In item 15, the respondents disagreed with a mean of 1.38 that watering of gardens in the morning and evening only to reduce high evapo-transpiration is a water management strategy to reduced water stress influenced by climate variability.

Table 9 shows community water management approaches adopted in the study area. Data presented in Table 9 shows that the community did not use security watch over water sources (e.g. using masquerades) as can be seen in item 1 of Table 9 . In item 2, a greater number of respondents agreed that the community regulate the period of water fetching by community members to manage water stress. However, the results obtained also show that the community do not use Prohibition of tree felling around, Watersheds Prohibition of sand mining in water bodies, Prohibition of fishing with chemicals, Prohibition of vegetable farming around water bodies, Prohibition of bathing in streams, Prohibition of fishing in certain parts of water bodies, Prohibition of cloth washing in certain parts of water bodies, Collective clearing of flora around water bodies by community members, Construction of dams to save water for scarcity period, Prohibition of bush burning around water bodies. However, the community use leak detection and repairs on public taps, construction of wells/boreholes as approaches to water management.

In Table 10, the measures taken to cope with climate variability as it relates to water stress in the study area is presented. From Table 10, 42.7\% of the respondents agreed that they have taken measures to cope with climate variability while $57.2 \%$ disagreed. This shows that there are low adaptation measures to cope with climate variability influenced water stress in the study area.

Table 9. Determination of community water management approaches.

\begin{tabular}{clccc}
\hline S/N & \multicolumn{1}{c}{ Community Approaches } & Used & Not Used & $\%$ \\
\hline 1 & Security watch over water sources (e.g. using masquerades) & 351 & 100 \\
2 & Regulating the period of water fetching by community members & 251 & 100 & 100 \\
3 & Prohibition of tree felling around Watersheds & - & 351 & 100 \\
4 & Prohibition of sand mining in water bodies & - & 351 & 100 \\
5 & Prohibition of fishing with chemicals & - & 351 & 100 \\
6 & Prohibition of vegetable farming around water bodies & - & 351 & 100 \\
7 & Prohibition of bathing in streams & - & 351 & 100 \\
8 & Prohibition of fishing in certain parts of water bodies & - & 351 & 100 \\
9 & Prohibition of cloth washing in certain parts of water bodies & - & 351 & 100 \\
10 & Leak detection and repairs on public taps & 351 & - & 100 \\
& Collective clearing of flora around water bodies by & - & 351 & 100 \\
11 & community members & - & 351 & 100 \\
12 & Construction of dams to save water for scarce period & 340 & 11 & 100 \\
13 & Construction of wells/boreholes & - & 351 & 100 \\
14 & Prohibition of bush burning around water bodies & & \\
\hline Source: & Field survey, 2019. & & &
\end{tabular}


Table 10. Measures taken to cope with climate variability in relation to water stress.

\begin{tabular}{ccc}
\hline Option & Frequency & Percentage (\%) \\
\hline Yes & 150 & 42.7 \\
No & 201 & 57.2 \\
Total & $\mathbf{3 5 1}$ & $\mathbf{1 0 0}$ \\
\hline
\end{tabular}

Source: Field survey, 2019.

Table 11 shows strategies for ameliorating water accessibility stress. The result in item 1 of Table 11 shows that provision of water supply infrastructure such as pipe borne water and boreholes, provision of new irrigation schemes and dams, engaging the beneficiary communities for which water provision is planned, Integrated water resources management (i.e. incorporating water supply, sanitation and hygiene into water development plans), creating awareness to the people as to the impacts or the impending impacts of climate change on water resources, Encouraging local watershed management, Clarifying the legal entitlement to water resources for all users, Traditional breeding of crop, forage, livestock and fishery species for improved resistance to climate stresses such as drought and flooding, implementation of seasonal climate forecasting, organizing gender specific technical training programmes in water resources management, provision of capacity building opportunities for women to diversify their sources of livelihood, Avoiding gender bias in household water provision, afforestation initiatives, and proper enforcement of laws on watershed protection can be good strategies for ameliorating the impacts of climate variability on water stress in the study areas as represented by a mean magnitude above the decision rule of 2.5. However, the respondents disagreed that mainstreaming gender in community water management, modification of crop calendars, and modification of irrigation techniques can be good strategies for ameliorating the impacts of climate variability on water stress in the study areas as represented by a mean magnitude below the decision rule of 2.5 .

\section{Conclusion/Recommendations}

The study was conducted on climate influenced challenges of accessibility to water by households downstream of the Upper Benue River Basin in the northeast region of Nigeria. This study found that variability in climatic conditions is directly proportional to water accessibility challenges and threats to households downstream of the Upper Benue River basin, which results in decreased quality and quantity of surface water as well as drying up of rivers and lakes. Water challenges induced by climate variability have significant effect on the livelihood of households. Communities and households downstream of the basin vulnerable to climate changes have developed strategies to contain water challenges thereby increasing their livelihood. These include surface water harvesting, reduction in the quantity of domestic water usage. Among others, the provision of water supply infrastructure such as pipe borne water and boreholes, provision of 
Table 11. Strategies for ameliorating climate influenced water accessibility stress.

\begin{tabular}{|c|c|c|c|c|c|c|c|}
\hline S/N & Strategies & SA & A & $\mathrm{D}$ & SD & Mean & Decision \\
\hline 1 & $\begin{array}{l}\text { Provision of water supply infrastructure } \\
\text { such as pipe borne water and boreholes }\end{array}$ & 344 & 7 & - & - & 3.98 & Agreed \\
\hline 2 & Provision of new irrigation schemes and dams & 317 & 34 & - & - & 3.90 & Agreed \\
\hline 3 & $\begin{array}{l}\text { Engaging the beneficiary communities for } \\
\text { which water provision is planned }\end{array}$ & 349 & 2 & - & - & 3.99 & Agreed \\
\hline 4 & $\begin{array}{l}\text { Integrated water resources management } \\
\text { (i.e. incorporating water supply, sanitation } \\
\text { and hygiene into water development plans) }\end{array}$ & 333 & 18 & - & - & 3.94 & Agreed \\
\hline 5 & $\begin{array}{l}\text { Creating awareness to the people as to the } \\
\text { impacts or the impending impacts of climate } \\
\text { change on water resources }\end{array}$ & 318 & - & 33 & - & 3.74 & Agreed \\
\hline 6 & Encouraging local watershed management & 312 & 39 & - & - & 3.88 & Agreed \\
\hline 7 & $\begin{array}{l}\text { Clarifying the legal entitlement to water } \\
\text { resources for all users }\end{array}$ & 219 & 132 & - & - & 2.72 & Agreed \\
\hline 8 & $\begin{array}{l}\text { Participatory risk assessment involving the } \\
\text { local people and all other stakeholders }\end{array}$ & 89 & 33 & 121 & 108 & 2.28 & Disagreed \\
\hline 9 & $\begin{array}{l}\text { Mainstreaming gender in community water } \\
\text { management }\end{array}$ & 21 & 12 & - & 318 & 1.24 & Disagreed \\
\hline 10 & $\begin{array}{l}\text { Traditional breeding of crop, forage, livestock } \\
\text { and fishery species for improved resistance to } \\
\text { climate stresses such as drought and flooding }\end{array}$ & 341 & 10 & - & - & 3.97 & Agreed \\
\hline 11 & Implementation of seasonal climate forecasting & 211 & 133 & - & 7 & 3.56 & Agreed \\
\hline 12 & Modification of crop calendars & 153 & - & - & 198 & 2.30 & Disagreed \\
\hline 13 & Modification of irrigation techniques & 169 & - & - & 182 & 2.44 & Disagreed \\
\hline 14 & $\begin{array}{l}\text { Organizing gender specific technical training } \\
\text { programmes in water resources management }\end{array}$ & 199 & - & 152 & - & 3.13 & Agreed \\
\hline 15 & $\begin{array}{l}\text { Provision of capacity building opportunities for } \\
\text { women to diversify their sources of livelihood }\end{array}$ & 206 & - & - & 145 & 2.76 & Agreed \\
\hline 16 & $\begin{array}{l}\text { Avoiding gender bias in household water } \\
\text { provision }\end{array}$ & 144 & 87 & - & 120 & 2.72 & Agreed \\
\hline 17 & Afforestation initiatives & 143 & 87 & 119 & 3 & 3.05 & Agreed \\
\hline 18 & $\begin{array}{l}\text { Proper enforcement of laws on watershed } \\
\text { protection }\end{array}$ & 213 & 41 & - & 97 & 3.05 & Agreed \\
\hline
\end{tabular}

Source: Field survey, 2019.

new irrigation schemes and dams, engaging the beneficiary communities for which water provision is planned; afforestation initiatives, and proper enforcement of laws on watershed would go a long way in ameliorating the impacts of climate variability on water challenges.

Based on the findings and conclusion of the study, the following recommendations are put forward:

1) The Upper Benue River Basin Development Agency as an agent for rural development should be restructured to focus on projects that create access to 
portable water for the rural dweller downstream the basin. This will engender sustainable development of the host communities of the authorities and expose the untapped potentials of these communities.

2) Stakeholders and the government should make proactive efforts to ensuring that alternative water sources are established in the study area to reduce water challenges among the rural populace.

3) The small-scale irrigation system by the Upper Benue River Basin Development Agency should be implemented. This has the advantage of greater presence among the low-income rural population in terms of income generation and scale of output, greater share of ownership by rural dwellers, stemming rural-urban migration, greater reliance on domestic capital and low intensity of managerial and technical skills.

\section{Acknowledgements}

The authors acknowledge all those who assisted in the process of data collection for this study as well as the independent reviewers whose comments helped to improve this paper.

\section{Conflicts of Interest}

The authors declare no conflicts of interest regarding the publication of this paper.

\section{References}

[1] Okeola, O.G. (2017) Challenges and Contradictions in Nigeria's Water Resources Policy Development: A Critical Review. International Journal of Science and Technology, 6, 1-19. https://doi.org/10.4314/stech.v6i1.1

[2] Omole, D.O. and Longe, E.O. (2008) An Assessment of the Impact of Abattoir Effluents on River Illo, Ota, Nigeria. Journal of Environmental Science and Technology, 1, 56-64. https://dx.doi.org/10.3923/jest.2008.56.64

[3] Odey, M.O. (2009) The Contradictions of Environmental Degradation, Economic Growth and Sustainable Development in Africa. In: Akinwumi, O., et al., Eds., Technology, Knowledge and Environment in Africa. International Conference Keffi, 5-7.

[4] Ele, S. (2013) Challenges of Water Supply in Nigeria since 1999 and its Consequences on Economic Development. International Journal of Economic Development Research and Investment, 4, 41-67.

[5] Babatola, J.O. and Oguntuase, A.M. (2008) Technical and Socio Economic Appraisal Supply Situation in a Typical Nigerian Centre. Nigerian Journal of Engineering, 14, 72-78.

[6] World Bank Group (2002) Report: Access to Safe Water Supply. http://www.worldbank.org/depweb/english/moules/environment/water/htm

[7] Ishaku, H.T., Rafee Majid, M., Ajayi, A.P. and Haruna, A. (2011) Water Supply Dilemma in Nigerian Rural Communities: Looking towards the Sky for an Answer. Journal of Water Resource and Protection, 3, 598-606. http://dx.doi.org/10.4236/jwarp.2011.38069

[8] United Nations World Water Assessment Programme (2020) The United Nations 
World Water Development Report 2020: Water and Climate Change. https://unesdoc.unesco.org/ark:/48223/pf0000372985.locale $=$ en

[9] Federal Ministry of Water Resources, Government of Nigeria, National Bureau of Statistics and United Nations Children's Fund (2020) Water, Sanitation and Hygiene: National Outcome Routine Mapping (WASH NORM) 2019: A Report of Findings. Federal Capital Territory, Abuja.

[10] World Water Assessment Programme (2019) The United Nations World Water Development Report 2019: Leaving No One Behind. United Nations Educational, Scientific and Cultural Organization, Paris.

[11] Intergovernmental Panel on Climate Change (2001) Climate Change 2001: Impacts, Adaptation and Vulnerability. Contribution of Working Group II on the Third Assessment Report of the Intergovernmental Panel on Climate Change (IPCC). Cambridge University Press, Cambridge, New York.

[12] World Health Organization (2015) UN-Water Global Analysis and Assessment of Sanitation and Drinking Water-Nigeria.

https://www.who.int/water_sanitation_health/monitoring/investments/nigeria-10-n ov.pdf?ua=1

[13] United Nations Children's Fund (2015) A Better Life for All. https://www.unicef.org/southafrica/SAF_overview_country.pdf

[14] Adah, P.O. and Abok, G. (2013) Challenges of Urban Water Management in Nigeria: The Way Forward. Journal of Environmental Management, 20, 111-121.

[15] United Nations Children's Fund and World Health Organization (2015) Progress on Sanitation and Drinking Water-2015 Update and MDG Assessment. United Nations Children's Fund and World Health Organization, New York, Geneva.

[16] Ezenwaji, E.E. (2012) Institutional Framework for Public Water Supply and Sanitation Management. In: Anyadike, R.C. and Obeta, M.C., Eds., Water Resources Development and Management in Nigeria, Department of Geography and Meteorology, University of Nigeria, Nsukka

[17] Obeta, M.C. and Chukwu, K.E. (2013) Water Supply and Demand in Nigeria. In: Anyadike, R.N.C. and Obeta, M.C., Eds., Water Resources Development and Management in Nigeria, Merit International Publication, Lagos, 155-164.

[18] Obeta, M.C. (2009) The Development of Rural Water Supply Infrastructure in Nigeria. In: Igbozurike, I. and Onyenechere, Eds., Rural Water Supply in Nigeria, Cape Publishers, Owerri, 402-410.

[19] Ezenwaji, E.E., Eduputa, B.M. and Okoye, I.O. (2016) Investigation into the Residential Water Demand and Supply in Enugu Metropolitan Area. American Journal of Water Resources, 4, 22-29.

[20] Toyobo, A.E. and Tanimowo, N.B. (2011) Evaluation of Rural Water Supply Schemes in Selected Communities in Oke-Ogun Area, Oyo State, Nigeria. Global Journal of Science Frontier Research, 11, 8-10.

[21] Olaleye, Y.L. (2010) The Contributions of the Doctrine of Citizens' Participation in Organization and Implementation of Community Development Project. European Journal of Scientific Research, 2, 12-13.

[22] Akpomunie, O.B. (2010) Self-Help as a Strategy for Rural Development in Nigeria: A Bottom-Up Approach. Journal of Alternative Perspectives in the Social Sciences. 2, 88-111.

[23] Marks, S.J. and Davis, J. (2012) Does User Participation Lead to Sense of Ownership for Rural Water Systems? Evidence from Kenya. World Development, 40, 1569-1576. https://doi.org/10.1016/j.worlddev.2012.03.011 
[24] Intergovernmental Panel on Climate Change (2014) Climate Change 2014: Impacts, Adaptation, and Vulnerability. Part A: Global and Sectoral Aspects. Cambridge University Press, Cambridge, 1132 p. https://doi.org/10.1017/CBO9781107415416

[25] Intergovernmental Panel on Climate Change (IPCC) 1998. The Regional Impacts of Climate Change: An Assessment of Vulnerability. Special Report of IPCC Working Group II [Watson, R.T., M.C. Zinyowera, and R.H. Moss (Eds.)]. Intergovernmental Panel on Climate Change, Cambridge University Press, Cambridge, United Kingdom and New York, NY, USA P. 517.

[26] Hulme, M. (1996) Climate Change and Southern Africa: An Exploration of Some Potential Impacts and Implications in the SADC Region. Climatic Research Unit, Norwich, $104 \mathrm{p}$.

[27] Lema, M.A. and Majule, A.E. (2009) Impacts of Climate Change, Variability and Adaptation Strategies on Agriculture in Semi Arid Areas of Tanzania: The Case of Manyoni District in Singida Region, Tanzania. African Journal of Environmental Science and Technology, 3, 206-218. https://doi.org/10.5897/AJEST09.099

[28] Raza, A., Razzaq, A., Mehmood, S.S., Zou, X.L., Zhang, X.K., Lv, Y. and Xu, J.S. (2019) Impact of Climate Change on Crops Adaptation and Strategies to Tackle Its Outcome-A Review, Plants, 8, 34. https://doi.org/10.3390/plants8020034

\section{Appendix 1}

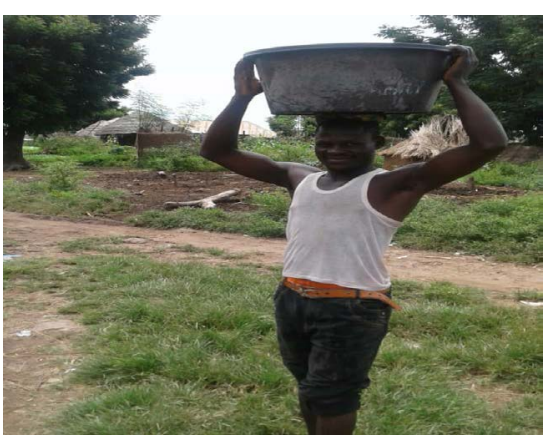

(a)

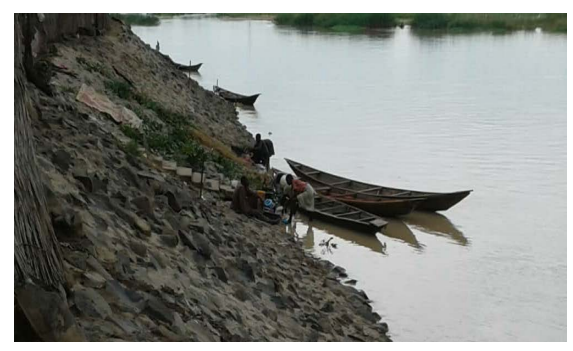

(b)

Figure A1. (a) A villager carrying water fetched from the stream; (b) Villagers fetching water on the bank of River Benue. 